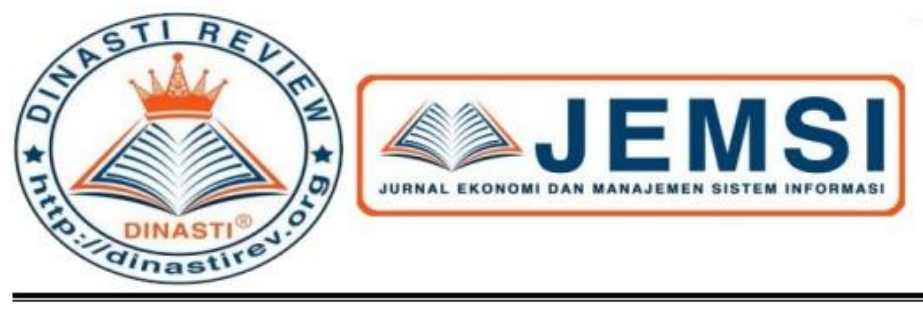

+62 878-9658-6407

087896586407 ()

https://dinastirev.org/JEMSI (-)

editor@dinastirev.org (G.)

\title{
BUSINESS ETHICS PADA CV. X
}

\section{Yanto Tjia}

Universitas Mercu Buana, Jakarta, Indonesia

\section{ARTICLE INFORMATION}

Received: 7 April 2020

Revised: 17 April 2020

Issued: 24 April 2020

Corresponding author:

Yanto Tjia

E-mail:

Tjia.yanto@yahoo.com

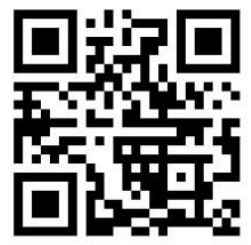

DOI:10.31933/JEMSI
Abstrak: Etika bisnis dapat di pahami sebagai salah satu cara melakukan kegiatan bisnis yang mencakup berbagai aspek yang berkaitan dengan individu, perusahaan, dan masyarakat secara holistic (suatu kesatuan). Dalam perusahaan, etika bisnis dapat membentuk berbagai nilai, norma, dan perilaku karyawan mulai dari staff hingga level pimpinan ketika akan membangun hubungan yang baik, adil, dan sehat dengan pelanggan, rekan kerja, pemegang saham, hingga masyarakat. Etika bisnis juga dapat menjadi salah satu standar bahwa perusahaan memiliki kualitas yang baik bagi seluruh karyawan, termasuk manajemen. Dalam penelitian ini penulis memiliki tujuan untuk mendeskripsikan bagaimana penerapan bagaimana penerapan terhadap prinsip etika bisnis pada CV. X. Adapun metode penelitian yang digunakan oleh penulis dalam penelitian kali ini adalah metode analisis deskriptif kualitatif dan studi literature, dengan tujuan mendapatkan informasi dengan cermat untuk mengetahui konsep dan pelaksanaan etika bisnis pada CV. X.

Kata Kunci: Business, ethics, etika bisnis

\section{PENDAHULUAN}

Di era digital saat ini pergerakan informasi berjalan dengan sangat cepat, seseorang dapat dengan mudah mencari berbagai informasi yang diperlukan olehnya hanya melalui genggaman tangan dan akses internet, namun tetap saja setiap orang perlu memperhatikan etika - etika yang berlaku di dalamnya. Entah itu etika mengutip, menyebarkan berita, hingga kepada etika berbalas pesan, padahal tanpa perlu bertemu atau bertatap muka secara langsung dengan orang - orang tersebut. Kenapa hal tersebut dapat terjadi, hal ini disebabkan karena individu yang dibentuk di dalam suatu masyarakat, akan mengalami sosialisasi untuk menerima aturan-aturan masyarakat yang sudah ada yang dikenal dengan sebutan etika.

Etika bisnis dapat di pahami sebagai salah satu cara melakukan kegiatan bisnis yang mencakup berbagai aspek yang berkaitan dengan individu, perusahaan, dan masyarakat secara holistic (suatu kesatuan). Dalam perusahaan, etika bisnis dapat membentuk berbagai nilai, norma, dan perilaku karyawan mulai dari staff hingga level pimpinan ketika akan membangun hubungan yang baik, adil, dan sehat dengan pelanggan, rekan kerja, pemegang saham, hingga masyarakat. Etika bisnis juga dapat menjadi salah satu standar bahwa 
perusahaan memiliki kualitas yang baik bagi seluruh karyawan, termasuk manajemen. Perusahaan yang baik adalah perusahaan yang mampu memenuhi kebutuhan para konsumen. Untuk melakukan proses jual beli yang baik, perusahaan harus memiliki suatu sistem yang mendukung proses jual beli tersebut. Terdapat peran penting yang dimiliki oleh manajemen dalam kaitannya terhadap pembentukan etika di tempat kerja sehingga sehingga dapat memuncul rasa keadilan kepada seluruh karyawan tanpa membedakan, dengan harapan yang dapat membangun rasa percaya karyawan (engagement) bahwa perusahaan tempat berkerja karyawan tersebut telah bertanggung jawab dan telah memperlakukan karyawan sebagaimana harusnya (sepatutnya dan sederajat).

Oleh karena itu berdasarkan pemikiran bahwa pelaksanaan etika dalam bisnis adalah hal penting, wajib dilakukan dan menciptakan citra bisnis yang baik dan etis bagi perusahaan, maka penulis memutuskan untuk melakukan analisa lebih lanjut mengenai pelaksanaan business ethics pada CV. X maka dijadikanlah topik paper dengan judul "Business Ethics pada CV. X”.

Adapun maksud dan tujuan penulis dalam pembuatan paper ini yaitu untuk mendapatkan informasi mengenai penerapan etika dalam bisnis yang dilakukan oleh CV. X, pada kegiatan bisnisnya untuk dapat mencapai tujuan perusahaan (visi dan misi) yang telah ditentukan. Serta untuk memastikan bahwa etika bisnis yang diterapkan oleh perusahaan telah sesuai dengan aturan, norma, dan ketentuan yang berlaku secara umum khususnya di lingkungan bisnis.

\section{KAJIAN PUSTAKA \\ Pengertian etika}

Secara etimologi kata "etika" pada awalnya muncul dari bahasa Yunani yang berasal dari gabungan dua kata yaitu "ethos" dan "ethikos". Ethos diartikan sebagai sebuah sifat, watak / kebiasaan. Ethikos dapat diartikan sebagai susila, sifat yang beradab, maupun seuatu kelakuan dan perbuatan yang baik.

Sedangkan menurut Webster Dictionary, secara etimologis, etika dapat diartikan sebaga suatu disiplin ilmu yang menjelaskan sesuatu yang baik dan yang buruk, mana tugas atau kewajiban moral, tau bisa juga mengenai kumpulan prinsip atau nilai moral.

Arti etika dapat dibedakan dari sisi praktis dan refleksi. Etika sebagai praktis dapat dimaknai sebagai sejauh mana baik nilai maupun moral diterapkan dan dilaksanakan dalam berbagai aktivitas dan kegiatan sehari hari, baik itu dalam bermasyarakat / bekerja. Pun, etika sebagai praktis dapat juga diartikan sebagai hal - hal apa yang dilakukan yang memiliki landasar dasar berupa nilai dan moral. Oleh karena ini, maka etika sebagai praktis dapat diartikan sebagai moral / moralitas: tuntutan mengenai apa yang harus dilakukan, tidak boleh dilakukan, pantas dilakukan dan sejenisnya. Etika sebagai refleksi merupakan bentuk dari sebuah pemikiran tentang moral, dimana kita dapat berfikir tentang apa yang dilakukan, dengan maksud lebih spesifik yaitu mengenai yang harus dilakukan atau tidak boleh dilakukan. Etika sebagai refleksi berfokus terhadap penilaian mengenai baik buruknya perilaku orang. (Hapzi Ali, 2020)

Terdapat dua pengertian etika: yaitu sebagai praktis dan sebagai refleksi. Sebagai praktis, etika berarti nilai dan norma yang baik yang dipraktikkan atau bahkan tidak dipraktikkan, walaupun seharusnya dipraktikkan. Etika sebagai praktis dapat disamaartikan dengan moral / moralitas yaitu mengenai apa yang harus dilakukan, apa yang boleh dilakukan, apa yang 
tidak boleh dilakukan, dan apa yang pantas dilakukan. Etika sebagai refleksi adalah bentuk dari pemikiran moral. (Bertens, 2013)

Etika tentunya memiliki kaitan erat dengan nilai - nilai / norma, suatu tatacara hidup dan aturan hidup yang baik, serta seluruh kebiasaan yang dianut dan diwariskan dari satu orang ke orang yang lain atau dari satu generasi ke generasi yang lain. (Hapzi Ali, 2020)

Etika bagi seseorang dapat terwujud dalam bentuk kesadaran moral yang memuat keyakinan "benar dan salah". Perasaan yang muncul bahwa dirinya adalah salah ketika akan melakukan sesuatu yang diyakininya tidak benar pada awalnya berasal dari norma-norma moral, value, belief, dan self-respect (menghargai diri) bila ia meninggalkannya. Tindakan yang diambil olehnya harus dapat ia pertangungjawabkan pada diri sendiri. Begitu juga dengan sikapnya sebagai bentuk respon terhadap orang lain bila pekerjaan tersebut mengganggu dirinya atau sebaliknya menyebabkannya mendapatkan pujian.

Ali (2020:7), menyatakan bahwa etika kerja adalah kondisi kehidupan yang penting untuk dicapai / dimiliki, terutama bagi manusia, karena didasarkan pada etos makhluk aktif, kode etik, atau selera permainan untuk memenuhi kebutuhan hidup.

Tentunya, dalam melaksanakan etika kerja secara teratur tiap karyawan perlu melaksanakannya dengan disiplin. Adapun jenis - jenis disiplin menurut Anwar (2020), yaitu disiplin preventif dan disiplin korektif. Disiplin preventif adalah "tindakan" di mana tindakan tersebut dapat mendorong seseorang untuk mematuhi berbagai ketentuan yang berlaku, sedangkan disiplin korektif adalah disiplin di mana karyawan, dalam hal ini, telah benarbenar melakukan pelanggaran yang berlaku sehingga dia diberi sanksi disipliner

\section{Teori - teori etika}

Terdapat beberapa teori - teori etika (Hapzi Ali, 2020), antara lain:

1. Teori Hak

Hak dan kewajiban dapat dianalogikan sebagai dua sisi dari uang logam yang sama. Hak memiliki dasar yaitu martabat manusia dan dapat dipahami bahwa martabat semua manusia itu sama. Karena itulah hak sangat cocok dengan pemikiran - pemikiran yang bersifat demokratis.

2. Teori Keutamaan (Virtue Theory)

Teori Keutamaan memandang sikap atau akhlak seseorang. Tidak ditanyakanapakah suatu perbuatan tertentu adil, atau jujur, atau murah hati dan sebagainya.

3. Teori Universalisme

Teori yang menyakan bahwa sesuatu dapat dianggap baik jika memberi manfaat / dampak bagi banyak orang.

4. Teori Intuisionisme

Teori ini berpendapat bahwa penilaian atas baik buruknya sesuatu, dapat diketahui dengan cara meyakini kepada intuisi yang dapat diartikan sebagai suatu pertimbangan rasa yang timbul dari bisikan diri / semacam ilham.

5. Teori Hedonisme

Teori ini berpendapat bawha sesuatu dianggap baik, sesuai dengan kesenangan yang mendatangkannya dan menganggap sesuatu yang mendatangkan kesusahan / penderitaan dinilai sebagai tidak baik. 


\section{Jenis - jenis etika}

Ada dua macam etika yang ketika akan menentukan baik atau buruknya perilaku manusia (Keraf, 2009), yaitu sebagai berikut:

\section{a. Etika Deskriptif}

Dapat diartikan sebagai bentuk etika yang berusaha menelaah secara kritis dan rasional sikap dan perilaku dari seorang manusia, serta berusaha memahami mengenai hal - hal yang dikejar oleh manusia dalam hidup ini sebagai sesuatu yang bernilai. Pada dasarnya, etika deskriptif memberikan fakta sebagai dasar untuk mengambil keputusan tentang perilaku atau sikap yang mau diambil.

\section{b. Etika Normatif}

Dapat diartikan sebagai bentuk etika yang berusaha menetapkan pemahaman kepada pada manusia mengenai berbagai sikap dan pola perilaku ideal yang seharusnya dimiliki oleh manusia dalam hidup ini adalah sesuatu yang bernilai. Pada dasarnya, etika normatif bertindak untuk memberi penilaian sekaligus pengertian mengenai norma - norma yang bertindak sebagai dasar dan kerangka atas tindakan yang akan diputuskan.

\section{Manfaat etika}

Adapun manfaat - manfaat etika menurut Qohar (2012), yaitu sebagai berikut:

1. Dapat membantu dalam membentuk suatu belief (keyakinan).

2. Dapat membantu membedakan mengenai hal yang boleh / tidak boleh dirubah.

3. Dapat membantu seseorang untuk mampu menentukan pendapat.

4. Dapat menjembatani semua dimensi atau nilai-nilai.

\section{Pengertian bisnis}

Bisnis merupakan sebuah usaha yang dijalankan yang tujuan utamanya adalah keuntungan. (Kasmir dan Jakfar, 2012)

Pendapat lain menyatakan bahwa bisnis adalah sebuah organisasi yang menyediakan barang atau jasa dengan maksud mendapatkan laba. (Griffin dan Ebert, 2007)

Dari pengertian diatas, penulis dapat menyimpulkan mengenai definisi bisnis sebagai sebuah kegiatan yang dilakukan oleh sebuah organisasi dengan cara menciptakan / menyediakan barang atau jasa dengan tujuan untuk mendapatkan keuntungan.

\section{Fungsi bisnis}

Terdapat 4 fungsi (kegunaan) dari bisnis yang berdasarkan aspeknya(Ahmad, 2019), antara lain:

a. Kegunaan berdasar bentuk

Bisnis jenis ini dapat diartikan sebagai bisnis yang memiliki fungsi utama yaitu merubah suatu benda menjadi benda lain dengan bentuk yang berbeda sehingga dapat memberikan manfaat sesuai fungsinya. Misalnya bisnis meubel, genteng, roti, sirup. 
b. Kegunaan berdasar tempat

Bisnis jenis ini dapat diartikan sebagai bisnis yang memiliki fungsi utama yaitu memindahkan sesuatu dari satu tempat ke tempat lain yang lebih bermanfaat, bergerak di bidang transportasi, baik itu angkutan manusia, angkutan barang, darat, laut, dan udara.

c. Kegunaan berdasar waktu

Bisnis jenis ini dapat diartikan sebagai bisnis yang memiliki fungsi utama yaitu menjalankan usaha penyimpanan dengan tujuan agar barang dari suatu waktu apabila kurang bermanfaat maka disimpan terlebih dahulu, kemudian disaat lain akan dikeluarkan bila barang itu sudah lebih bermanfaat. Misalnya: container di pelabuhan, system pergudangan di berbagai pelabuhan.

\section{d. Kegunaan berdasar pemilikan}

Bisnis jenis ini dapat diartikan sebagai bisnis yang memiliki fungsi utama yaitu yang menjalankan usahanya untuk menciptakan/memenuhi kegunaan pemilikan terhadap suatu barang/jasa. Contohnya: pertokoan, perdagangan.

\section{Tujuan bisnis}

Adapun beberapa tujuan dalam bisnis (Madnasir dan Khoiruddin, 2012), antara lain:

a. Menciptakan dan pengadaan barang atau jasa yang dibutuhkan oleh manusia, baik individu, komunitas maupun masyarakat secara keseluruhan.

b. Mendapatkan pendapatan yang diinginkan agar lebih besar daripada biaya atau ongkos yang telah dikeluarkan oleh pengelola bisnis.

c. Menciptakan nilai tambah bagi seluruh pengelola bisnis / pemegang kepentingan dan masyarakat.

d. Menciptakan lapangan kerja bagi seluruh masyarakat.

e. Meningkatkan kesejahteraan bagi seluruh pihak-pihak yang terlibat dalam bisnis tersebut (pemilik, pekerja dll).

\section{Pemegang kepentingan dalam bisnis}

Pemegang kepentingan (Stakeholders) dapat diartikan sebagai orang - orang yang mempunyai kepentingan dalam bisnis (Madura, 2007), jenis - jenis stakeholder yaitu:

a. Pemilik

1) Wiraswasta (entrepreneur) yaitu seseorang yang mengorganisasi, mengelola, dan mengasumsi resiko yang dihadapi untuk dapat memulai bisnis.

2) Pemegang saham (shareholder / stockholder). Saham diartikan sebagai sertifikat kepemilikan suatu perusahaan, sedangkan Pemegang saham adalah seseorang yang secara sah memiliki satu atau lebih lembar saham pada perusahaan.

b. Karyawan

1) Karyawan perusahaan diangkat untuk menyalurkan operasi perusahaan. 
2) Manajemen adalah sekumpulan karyawan yang mempunyai tanggung jawab dalam mengelola berbagai pekerjaan yang ditugaskan kepada karyawan lain dan membuat keputusan penting perusahaan.

c. Kreditor Institusi keuangan atau individu yang memberikan pinjaman.

d. Pemasok Penyedia bahan baku dan mengantarkannya tepat waktu.

e. Pelanggan Pihak yang menerima produk atau jasa dengan nilai / harga tertentu.

\section{Pengertian etika bisnis}

Hapzi Ali (2020), mendefinisikan etika bisnis sebagai suatu cabang dari filosofi yang berkaitan dengan kebaikan atau moralitas dari perilaku manusia.

Selain itu terdapat juga pendapat lain mengenai etika bisnis, yang mendefinisikan etika bisnis sebagai suatu ajaran untuk dapat membedakan antara salah dan benar guna memberikan tambahan opini kepada setiap pemimpin perusahaan ketika mempertimbangkan untuk mengambil keputusan strategis memiliki kaitan dengan masalah moral yang kompleks (Hill dan Jones, 1998)

Etika bisnis dapat dijalankan pada tiga taraf yaitu taraf makro, meso, dan mikro. Pada taraf makro, etika bisnis mempelajari aspek-aspek moral dari sistem ekonomi sebagai keseluruhan atau pada skala besar. Pada taraf meso (menengah), etika bisnis dipergunakan dalam menyelidiki masalah-masalah etis di bidang organisasi. Sedangkan pada taraf mikro, yang di fokuskan ialah individu dalam hubungan dengan ekonomi atau bisnis. (Bertens, 2013)

Etika bisnis dalam penerapannya dapat digunakan untuk menjadi suatu standar maupun pedoman bagi seluruh karyawan dalam berbagai lapisan jabatan mulai dari pegawai hingga manajemen, serta dapat dijadikan sebagai tuntunan dalam melaksanakan pekerjaan seharihari yang dilandasi oleh moral yang luhur, jujur, transparan dan sikap yang professional, serta sejalan dengan budaya atau kultur perusahaan. Tentunya hal ini diharapkan mampu menciptakan keunggulan kompetitif bagi perusahaan, minimal dari sisi citra perusahaan yang baik dimata para pelanggan lewat pembuatan perencanaan - perencanaan strategis dan pelaksanaan atas eksekusi yang baik.

\section{Prinsip etika bisnis}

Prinsip etika bisnis menurut Sonny Keraf setidaknya ada lima yang dijadikan titik tolak pedoman perilaku dalam menjalankan praktik bisnis (Agus dan Ardana, 2009), yaitu:

a. Prinsip Otonomi

Prinsip otonomi menunjukkan sikap kemandirian, kebebasan, dan tanggungjawab. Orang yang mandiri dapat diartikan sebagai seseorang yang dapat mengambil suatu keputusan dan melaksanakan tindakan berdasarkan keputusan tersebut dengan bergantung kepada kemampuan sendiri dan keyakinannya, terbebas dari tekanan, hasutan, dan ketergantungan kepada pihak lain.

b. Prinsip Kejujuran 
Prinsip ini menitikberatkan kepada sikap yang menyatakan bahwa apa yang orang tersebut pikirkan adalah apa yang dikatakan, dan apa yang dikatakan adalah yang dikerjakan (walk the talk). Prinsip ini juga menyiratkan kepatuhan dalam melaksanakan berbagai komitmen, kontrak, dan perjanjian yang telah disepakati, dengan integritas, dan kejujuran.

c. Prinsip Keadilan

Prinsip ini menitikberatkan kepada sikap untuk memperlakukan semua pihak dengan adil, tanpa membeda-bedakan berbagai aspek misalnya: aspek ekonomi, aspek hukum, maupun aspek lainnya.

d. Prinsip saling Menguntungkan

Prinsip ini menitikberatkan terhadap sifat saling menguntungkan, serta menanamkan kesadaran dalam berbisnis bahwa dalam setiap keputusan strategis / keputusan bisnis yang diambil hendaknya berlandaskan prinsip win-win solution, artinya dalam setiap keputusan dan tindakan bisnis harus diusahakan agar semua pihak yang terlibat serta merasa diuntungkan.

e. Prinsip Integritas Moral

Prinsip ini menitikberatkan terhadap pemahaman untuk tidak merugikan orang lain dalam segala keputusan dan tindakan bisnis yang diambil.

\section{Pentingnya etika bisnis}

Tentunya, etika bisnis memiliki peran tidak hanya dalam kehidupan individu, maupun bermasyarakat, namun juga perlu dimiliki perusahaan sehingga dapat membentuk perusahaan yang kokoh, kuat, serta memiliki keunggulan kompetitif dan kemampuan menciptakan value yang bernilai tinggi, dimana dalam pelaksanaannya agar dapat tercapai hal tersebut pastilah diperlukan suatu landasan yang kuat, solid, dan kokoh agar dapat mencapai hal - hal tersebut. Agar hal tersebut dapat dicapai, tentunya perusahaan perlu memulai langkah awalnya dari penyusunan perencanaan strategis, pembentukan organisasi yang baik, pembuatan dan pengontrolan sistem prosedur yang transparan didukung oleh budaya perusahaan yang handal serta penerapan etika perusahaan terlaksana secara konsisten, dan kongruen.

Pentingnya etika bisnis dalam kelangsungan perusahaan adalah sebagai berikut (Muhammad, 2004):

1. Tugas utama etika bisnis dipusatkan pada upaya mencari cara untuk menyelaraskan kepentingan strategi suatu bisnis dengan tuntunan moralitas.

2. Etika bisnis memiliki tugas dalam melakukan perubahan kesadaran masyarakat tentang bisnis, dengan cara memberikan suatu pemahaman baru yaitu bahwa bisnis tidak dapat dipisahkan dari etika.

\section{METODE PENELITIAN}

Metode penelitian yang digunakan penulis adalah menggunakan metode deskripsitf kualitatif dan studi literatur. Metod penelitiane deskriptif kualitatif dapat diartikan sebagai sebuah metode penelitian yang berpusat pada status sekelompok manusia, objek, kondisi, atau suatu sistem pemikiran, maupun suatu kelas peristiwa pada masa sekarang dengan tujuan 
untuk mendeskripsikan, menggambarkan, serta melukiskan sesuatu secara sistematis, faktual dan akurat mengenai fakta, sifat, serta hubungan antar fenomena yang diselidiki, (Nazir:2009).

Sedangkan metode penelitian studi literatur diartikan sebagai penelitian yang dilakukan dengan cara mengumpulkan dan mempelajari berbagai literatur seperti buku, majalah yang berkaitan dengan masalah dan tujuan penelitian. Teknik ini dilakukan dengan bertujuan untuk mengungkapkan relevansi antara berbagai teori yang ditemukan, dan dikaitkan dengan dengan permasalahan yang sedang diteliti sebagai bahan rujukan dalam pembahasan hasil penelitian, (Danial dan Warsiah, 2007)

Subjek pada penelitian ini adalah CV. X, yang berada di Jawa Barat. Objek penelitian pada penelitian kali ini adalah penerapan - penerapan etika bisnis pada CV. X.

\section{HASIL DAN PEMBAHASAN \\ Penelitian terdahulu}

Dalam penelitian kali ini penulis membahas mengenai pelaksanaan business ethics di suatu perusahaan, dan sudah banyak riset-riset sebelumnya membahas hal ini. Dalam penelitian kali ini, penulis menjadikan beberapa penelitian yang ada sebagai dasar landasan (referensi) dalam memperkaya bahan kajian pada topik penelitian yang diambil penulis. Berikut merupakan penelitian terdahulu terkait dengan konteks penelitian yang dilakukan penulis, diantaranya adalah Rudi (2018), Pratiwi (2019), dan Andreas (2019), seperti yang tertuang dalam tabel di bawah ini.

Tabel 1. Penelitian - penelitian terdahulu

\begin{tabular}{ll}
\hline Nama Peneliti & Judul Penelitian \\
\hline $\begin{array}{l}\text { Rudi, dan Hapzi Ali. } \\
(2018)\end{array}$ & Concepts and theories of business ethics Kalbe Farma, Tbk. \\
\hline Pratiwi Triasti, dan & Business ethics \& Good corporate governance pada PT. Sumber \\
Hapzi Ali. (2019) & Alfaria Trijaya Tbk. \\
\hline $\begin{array}{l}\text { Andreas Fabian dan } \\
\text { Hapzi Ali. (2019) }\end{array}$ & Etika bisnis pada PT. Gudang Garam, Tbk. \\
\hline
\end{tabular}

\section{Etika bisnis CV. X}

1. Terhadap internal perusahaan

a. Tanggung jawab karyawan

A. Seluruh karyawan / pegawai, serta keseluruhan dari pendukung Perusahaan (CV) wajib melaksanakan tugasnya dengan itikad baik, dan bertanggung jawab secara penuh.

B. Setiap karyawan / pegawai yang terlibat dalam pelaksanaan kegiatan operasional / kegiatan manajemen Perusahaan (CV) diharapkan bertanggung jawab untuk untuk:

1. Memahami, dan melaksanakan seluruh peraturan Perusahaan (CV) yang berlaku dalam seluruh aspek kegiatan usaha Perusahaan (CV).

2. Memahami, dan melaksanakan seluruh keputusan yang telah ditentukan oleh manajemen dan atasan. 
3. Melaporkan semua penyimpangan yang ditemukan kepada Human Resource Department, serta Manajemen sesuai dengan jenis kategori penyimpangan.

C. Setiap karyawan wajib melaporkan serta berkomunikasi kepada Kepala Human Resource Department jika terdapat situasi - situasi yang disebutkan namun tidak terbatas pada:

1. Jika terdapat kegiatan / tindakan usaha yang bertentangan dengan Kode Etik dan memiliki potensi merugikan Perusahaan (CV).

2. Jika terdapat kegiatan / tindakan usaha yang dapat menyebabkan munculnya / terjadinya konflik dengan standar perilaku yang telah di tetapkan berdasarkan Kode Etik ini.

3. Jika ditemukan / terdapatnya ketidakjelasan / ambiguitas tentang standar ketentuan mengenai apa yang diperbolehkan maupun tentang hal yang tidak diperbolehkan.

4. Jika terjadinya penyimpangan dari standar perilaku pada suatu kondisi khusus / tertentu, yangmana telah diatur melalui persetujuan Manajemen Perusahaan (Direksi).

D. Kebijakan Perusahaan (CV) mengenai tanggung jawab karyawan dalam menggunakan wewenang dan jabatannya di Perusahaan (CV) meliputi:

1. Menggunakan secara sadar utuh, dan bertanggung jawab kepada seluruh kepentingan pencapaian Perusahaan (CV) dan tidak untuk kepentingan pribadi atau pihak-pihak tertentu diluar Perusahaan (CV).

2. Berkomitmen dan bertanggung jawab secara penuh dalam penggunaan seluruh data, informasi, aset, harta dan/atau fasilitas perusahaan semata - mata untuk kepentingan Perusahaan (CV), tidak untuk kepentingan pribadi atau pihakpihak tertentu diluar perusahaan $(\mathrm{CV})$.

3. Selalu berkomitmen dalam menjaga nama baik Perusahaan (CV) yang tercermin dalam sikap dan perilaku, baik di luar maupun di dalam Perusahaan (CV).

$\mathrm{b}$, Tanggung jawab manajemen

A. Memberikan informasi kepada karyawan akan kewajibannya dalam menjalankan usaha serta memberikan arahakan kepada karyawannya untuk melaksanakan kewajiban-kewajiban yang telah ditentukan tersebut.

B. Menerapkan dan mengontrol proses dan standar prosedur dalam fungsinya untuk memastikan setiap karyawan mematuhi tugas, tanggung jawab, dan kewajibannya dalam setiap kasus penyimpangan yang terjadi agar selalu dapat dapat dideteksi, dilaporkan, untuk kemudian ditindaklanjuti. 
C. Memantau dan memastikan kepatuhan dari setiap karyawan atas kewajiban - kewajiban yang telah ditetapkan kepada dirinya.

2. Terhadap eksternal perusahaan

a. Perlakuan atas informasi rahasia

Demi menjaga nama baik Perusahaan (CV), maka Karyawan wajib melindungi segala bentuk informasi milik pihak-pihak lain yang diketahuinya. Untuk itu Karyawan tidak berhak menyebarluaskan informasi sebelum diketahui/disepakati secara formal oleh pihak pihak yang terlibat, atau yang berdasarkan komitmen dengan pihakpihak tertentu.

Informasi Rahasia Perusahaan (CV) adalah dokumen dan/atau informasi strategis yang dibuat dan/atau diperoleh Perusahaan (CV) yang tidak boleh diungkapkan dan diberikan kepada pihak luar dengan pertimbangan menjaga keunggulan kompetitif Perusahaan (CV) dan/atau mematuhi perjanjian-perjanjian atau peraturan perundangan yang mewajibkan Perusahaan (CV) menjaga kerahasiaan informasi tersebut.lain harus dirahasiakan.

b. Larangan untuk menerima pemberian hadiah dari pihak luar

1. Hadiah/Bingkisan/Gratifikasi

Perusahaan $(\mathrm{CV})$ tidak menyetujui pemberian atau penerimaan, segala bentuk hadiah/bingkisan/gratifikasi dalam bentuk apa pun kepada / dari pihak-pihak lain sebagai bentuk balas jasa atau ungkapan simpati sehubungan dengan pekerjaan/jabatan Karyawan di dalam Perusahaan (CV), termasuk menawarkan atau meminta hadiah/bingkisan/gratifikasi tersebut. Setiap penerimaan hadiah/bingkisan/gratifikasi dari pihak luar sehubungan dengan pekerjaan/jabatan Karyawan di Perusahaan (CV), wajib dilaporkan kepada Human Resource Department, dan atasan karyawan yang bersangkutan.

2. Entertainment / Hiburan

Pemberian hiburan hanya dapat dilakukan oleh karyawan mulai dari level tertentu dengan tujuan untuk kepentingan Perusahaan (CV) dan dilaksanakan sesuai dengan ketentuan yang berlaku serta tidak bertentangan dengan nilai-nilai Perusahaan (CV).

3. Kode etik atas penyuapan

Perusahaan (CV) melarang adanya penyuapan dalam berbagai bentuk kepada pihak manapun. Penyuapan adalah usaha yang dilakukan oleh pihak-pihak lain kepada Karyawan dan/atau sebaliknya dengan tujuan mempengaruhi pengambilan keputusan dan dilakukan semata-mata demi kepentingan/keuntungan pribadi kedua belah pihak. 


\section{KESIMPULAN DAN SARAN}

\section{Kesimpulan}

Implementasi etika bisnis CV. $\mathrm{X}$ adalah sebagai berikut:

1. Perusahaan (CV) telah membuat suatu pedoman tentang perilaku etis (Code of conduct), yang memuat nilai-nilai etika berbisnis dan mengembangkan Code of conduct menyesuaikan dengan perkembangan keadaan Perusahaan (CV) dan perubahan peraturan perundang-undangan.

2. Perusahaan $(\mathrm{CV})$ telah mendukung dan menerapkan upaya anti gratifikasi dan penyuapan

3. Perseoran tekah memastikan pelaksanaan perlindungan atas informasi rahasia

\section{Saran}

Dari hasil kajian penulis tersebut, beberapa hal yang menjadi rekomendasi dari penulis adalah sebagai berikut:

1. CV. X perlu mempertegas aturan yang berlaku untuk semua kalangan karyawan, mulai dari staff hingga manajemen khususnya dalam konteks menjalankan roda bisnis operasional sehari - hari, namun akan lebih baik lagi jika hal tersebut bisa ditelurkan dalam petunjuk perilaku yang lebih detail dalam format kode etik / peraturan perusahaan sub bagian peraturan karyawan.

2. Sinergitas Human Resources Department dengan departemen lain bisa terlakasana hanya dengan komitmen dari manajemen puncak yang baik untuk turut melakukan, sehingga untuk implementasi etika dan budaya kerja di CV. X dapat menjadi konkrit dan berdampak kepada citra perusahaan.

\section{DAFTAR RUJUKAN}

Agus, Sukrisno dan I Cenik Ardana. 2009. Etika Bisnis dan Profesi. Jakarta: Salemba Empat

Ali, H. 2016. Concepts and Theories of Business Ethics. Universitas Mercu Buana.

Ali, H. 2020. Modul Business Ethics \& Good Governance. Universitas Mercu Buana. Jakarta.

Ali, H., Mukhtar, Sofwan. 2016. Work ethos and effectiveness of management transformative leadership boarding school in the Jambi Province. International Journal of Applied Business and Economic Research, 14(11), 7451-7471.

Anwar, K., Muspawi, M., Sakdiyah, S. I., \& Ali, H. (2020). The Effect of Principal's Leadership Style on Teachers' Discipline. Journal of Talent Development and Excellence, 100-110.

Bertens, K. 2013. Etika. Yogyakarta: Kanisius.

Danial, E dan Warsiah, Warsiah. 2009. Metode Penulisan Karya Ilmiah. Bandung: Laboratorium Pendidikan Kewarganegaraan.

Griffin, Ricki W dan Ronal J Ebert. 2007. Bisnis Edisi 8. Jakarta: Erlangga. 
Jones, G.R. andC.W. Hill. 1988. Transaction Cost Analysis of Strategy-Structure Choice, Strategic Management Journal, Vol.9, pp.159-172.

Kasmir \& Jakfar. 2012. Studi Kelayakan Bisnis. Cetakan ke Delapan. Jakarta: Kencana.

Keraf, Sonny. 2009. Etilm Bisnis Tuntutan dan Relevansinya. Yogyakarta: Pustaka Filsafat.

Madnasir, Madnasir dan Khoiruddin, Khoiruddin. 2012. Etika Bisnis Dalam Islam. Bandar Lampung: Fakultas Syariah IAIN Raden Intan.

Madura, Jeff. 2007. Introduction to Business. Edisi Keempat. Jakarta: Salemba Empat

Muhammad, Muhammad. 2004. Etika Bisnis Islami. Yogyakarta: UPP AMP YKPN.

Nazir, Mohammad. 2009. Metode Penelitian. Jakarta: Ghalia Indonesia.

Pramuditya, Andreas Fabian dan Ali, Hapzi. 2020. https://www.slideshare.net/AndreasFabianPramudi/2-be-amp-gg-andreas-fabianpramuditya-hapzi-ali-business-ethics-of-pt-gudang-garam-tbk-universitas-mercubuana-2018-126063969. (28 Maret 2020, jam 17:00)

Rudi, Rudi dan Ali, Hapzi. 2018. https://www.slideshare.net/RudiRudi11/1-be-gg-rudihapzi-ali-ethics-and-business-concept-and-theory-universitas-mercu-buana-2018. (25 Maret, jam 19:22)

Qohar, Adnan. 2012. Jurnal Pengertian Etika dan Profesi Hukum. http://rhinii.wordpress.com/2013/10/12. (26 Maret 2020, jam 14:12).

Triasti, Pratiwi, dan Ali, Hapzi. 2019. https://www.academia.edu/41557961/BUSINESS_ETHIC_and_GOOD_CORPO RATE_GOVERNANCE_PADA_PT._SUMBER_ALFARIA_TRIJAYA_TBK. (25 Maret 2020, jam 18:45)

Webster, Merriam. 2004. Merriam Webster's Collegiate Dictionary. United States of America: Merriam Webster Incorporated 